mjr. Mgr. Terezie Němcová, MPA

Proces targetingu na príkladu Libye

Vojenské rozhledy, 2015, roč. 24 (56), č. 1, s. 61-71, ISSN 1210-3292 (tištěná verze), ISSN 2336-2995 (on-line). Článek prošel recenzním řízením.

\title{
Targeting Process on the Example of the Libya Case
}

\section{Abstrakt:}

Ochrana civilniho obyvatelstva před Kaddáfiho režimem, to byl jasný mandát OSN pro vojenskou intervenci $v$ Libyi v roce 2011. Nejen nový př́stup $k$ vedení boje s terorismem po 11. záŕi 2001, ale i nutná změna př́stupư $k$ vedení bojových operaci koaličnich jednotek, jak ukázal právě ozbrojený konflikt v Libyi, si nevyhnutelně vyžádaly i nový pohled na pojetí a na př́stup k procesu targetingu jako procesu výběru a stanovení priority cílů a odpovídající reakce na ně v souladu s operačními požadavky a schopnostmi jednotek, synchronizaci jednotek NATO, a to především s ohledem na kolaterální škody s dopadem na ochranu civilního obyvatelstva. A právě operace Unified Protector je toho jasným přikladem.

\section{Abstract}

Protection of the civilian population against the Gaddafi regime, it was a clear UN mandate for military intervention in Libya in 2011. Not only a new approach to leading the fight against terrorism after 11 September 2001, but also requires a change in approaches to conducting combat operations coalition forces, as shown by the recent armed conflict in Libya, inevitably required a new perspective on the concept and approach to the process of targeting as the process of selecting and prioritizing targets and responding to them in accordance with operational requirements and capabilities of units, synchronization of NATO forces, particularly with regard to collateral damage with an impact on the protection of civilians. And Unified Protector operation is a clear example.

\section{Klíčová slova:}

targeting, cíl, OUP, Libye, kolaterální škody, mezinárodní humanitární právo, proces targetingu, vyhodnocování, plánování, synchronizace procesu, NATO CDE metodologie.

\section{Key words:}

Targeting, target, OUP, Libya, collateral damage, international humanitarian law, the process of targeting, evaluation, scheduling, process of synchronization, NATO CDE metodology. 


\section{Úvod}

Vojenská intervence v Libyi byla zahájena na základě rezoluce č. 1973 Rady bezpečnosti OSN, přijaté dne 17. března 2011. Tímto mandátem oprávnila OSN členské státy $\mathrm{k}$ použití síly $\mathrm{k}$ ochraně civilního obyvatelstva, a to především prosazením bezletové zóny nad Libyí. Ovšem již před schválením této rezoluce proběhla evakuace zahraničních občanů, která probíhala nejen letecky, ale i námořní cestou. V této souvislosti taktéž proběhlo několik utajovaných evakuací pod vedením Německa, Velké Británie a Nizozemí. Tyto evakuace, které byly utajované, měly za cíl dostat zahraniční občany z rizikových oblastí, kde bylo obtížné dostat se běžnými spoji. Jednotlivé zúčastněné státy NATO operující pod záštitou OSN používaly různé názvy národních operací např. USA,Odyssey Dawn“, Francie „Harmattan“ a Velká Británie „Ellamy“. Dne 23. března 2011 bylo rozhodnuto o společném velení NATO a operace od této doby nesla název Operation Unified Protector (OUP). I když je nutno podotknout, že Belgie se rozhodla pro vlastní operaci „Freedom Falcon“.

V několika málo týdnech po vypuknutí krize vedlo tedy NATO mezinárodní koaliční operaci v Libyi, kdy nemělo ve své podstatě čas zabezpečit ujednocení všech konsekvencí. Tyto nedostatky v prŕípravě bylo nutné nahradit stanovením jasného směru a jasných jednotných postupů. Ihned po zahájení operace se objevilo několik nedostatků. Jedním z hlavních nedostatků byla pro tuto, z pohledu targetingu, dynamickou/kinetickou operaci především nedostatečná kapacita přísunu prověřených a potvrzených informací od zpravodajských služeb. NATO tedy nemělo dostatek kvalifikovaného personálu k zabezpečení všech požadavků na udržení hladkého průběhu takovéto operace. Došlo na spoléhání se na kritické americké prvky, např. SEAD (Suppresion of Enemy Air Defences) / EW (Electronc Warfare), (Intelligence, Surveillance and Reconnaissance) ISR, jež byly nezbytné pro úspěch. Počáteční struktura velení a řízení se ukázala jako neefektivní a situace v místě operačního působení si vyžádala v této oblasti rychlé změny. Toto a mnoho dalších úskalí bylo zveřejněno ihned po zahájení operace v médiích, která začala vyslovovat názor, že NATO není vhodné pro řešení tohoto druhu krizové situace, a že je vysoce závislé na dobré vůli členských států, a to zejména proto, že musí odevzdaně čekat, zda jsou vůbec jednotlivé členské státy ochotny připojit se tomuto druhu vojenské operace. I když je pravda, že tímto bylo poukázáno na mnohé problémy a diskutabilní oblasti, hlubší analýza ukazuje poněkud jiný př́iběh. Přes všechny nedostatky dokázalo NATO s velkým úspěchem překonat mnohé strategické, operační a taktické problémy. Při pohledu na to, kolik bylo zvládnuto problémů a kritických oblastí během samotného průběhu OUP, musíme shledat, že byla tato operace př́kladem úspěšné adaptace uprostřed boje.

„Na prvním místě je pro mě targeting - schopnost spojit zpravodajství, sledování, prükum a vytvořit synchronizovaný, precizní proces targetingu, který nezpiosobuje kolaterální škody. “ To jsou slova, která pronesl v rozhovoru pro média k tématu OUP tehdejší nejvyšší vojenský velitel NATO admirál James G. Stavridis.

Cílem tohoto článku je nejen zkoumat proces targetingu a jeho vztah ke zpravodajskému a operačnímu plánování, ale i zanalyzovat, jaké byly identifikovány problémy prímo v průběhu vedení OUP, jak byla změněna struktura velení a rrízení pro tuto operaci, které nedostatky bylo nutné překonat, jaké bylo celkové sdílení informací mezi jednotlivými účastnícími se národy a jakou roli v procesu targetingu při OUP sehrálo samotné NATO jako jakýsi „stmelovatel“ účastnících se členských států. 


\section{Vliv struktury velení a řízení na OUP}

Velení, cíle, pokyny a záměr velitele, to je nejdůležitější fáze procesu targetingu. [1] Jedná se o převod celkové strategie do jednotlivých úkolů operace. Je to převod politických a vojenských cílů, pokynů a záměru do konkrétních akcí, které logicky ústí do požadovaného konečného stavu operace. Pokud jsou strategie a pokyny nedostatečné, taktické úkoly nedostatek jen zdůrazní. Důsledky nedostatečné struktury velení a řízení, která způsobuje špatné vedení targetingu, může mít dramatické strategické dopady na velitele společného úkolového uskupení (Commander Joint Task Force - CJTF) operace. „Bez ohledu na použití nejmodernějšich a nejpřesnějšich zbraní, pokud chybi u targetingu úsili o jasnou strategii nebo o postupy, které nejsou mimo pravidla války, může to znamenat kompletní porážku ", uvádí velitel US Navy Intell. John Patch.

Targeting je především o účincích, zda se bude jednat o dobré nebo špatné účinky, silně závisí na pokynech velitele společných sil (JFC D \& G) a způsobu, jakým se provádí. Pro OUP byl vytvořen Společný komponent vzdušných sil (Combined Forces Air Component - CFAC) a pro vytvořený prvek byla působnost zcela jasná, nebot' byla odvozena z operativní a strategické úrovně operačního plánu (OPLAN). Strategické politické vojenské vedení bylo dáno z úrovně Severoatlantické rady (North Atlantic Council - NAC), příslušných rezolucí Rady bezpečnosti OSN a z cílů vydaných v Berlíně 14. dubna 2011: „CFAC má za úkol provádět letecké operace ve vzdušném prostoru společného operačního prostoru s cílem chránit civilisty v Libyi za použití kinetických a nekinetických prostředkủ proti agresivním aktérům, kteři útoči nebo hrozí, že budou útočit na civilisty nebo $v$ civilních obydlených oblastech, a prosazování embarga na použití leteckých zbraňových systémů a bezletové zóny. “ [2]

OPLAN stanovuje právní rámec a základní pokyny pro targeting. NAC schválila cíle pro použití letálních a neletálních prostředků, zakázané a režimové cíle. Vymezila pravidla nasazení (Rules of Engagement - ROE), použití síly a metodologii odhadu kolaterálních škod k zabránění ztrát na lidských životech. Stručně řečeno OPLAN popisuje to, co má dělat každý jednotlivý funkční prvek v souladu s cílem dané operace a v souladu s mezinárodním právem, kdy OPLAN vychází z procesu operačního plánování, kde má zpravodajský cyklus zvláštní úlohu. V rámci NATO vychází OPLAN z procesu spolupráce mezi strategickou, operační a taktickou úrovni. Vzhledem k tomu, že každý národ má své slovo, je zde vyžadována precizně vystavěná struktura velení a řízení od politické až po taktickou úroveň. Pokud není zajištěno jednotné velení a jednotné úsilí, dojde zákonitě k nežádoucím účinkům a k nežádoucím strategickým důsledkům. Tato zásadní podmínka na úspěch hrála stěžejní roli při zahájení OUP v Libyi. Rafale a Mirage stíhací letouny francouzského letectva zaútočily v oblasti Benghází odpoledne 19. března 2011, bez toho aniž by byl vyřazen Kaddáfího integrovaný systém protivzdušné obrany (Integrated Air Defence System - IADS). Toto je první př́klad nedostatku operační koordinace mezi USA, vedoucím národem operace Odyssey Dawn a francouzským spojencem. Dalším př́kladem je nasazení amerických strategických bombardérů B-2 (které zaútočily na libyjská letiště) o stejném víkendu, kdy toto nasazení trvalo zhruba šest hodin, ovšem bez oficiálního rozkazu. Tento příklad ukazuje na nesoulad mezi americkými taktickými záměry a pomalým politickým rozhodovacím procesem. Operaci Odyssey Dawn řídily USA z AFRICOM velitelství v Ramsteinu, přičemž jednotlivé národy jako např. Francie řídily své operační nasazení z území svého 
státu (tzv. Reachback). Ne všechny země zapojené do Odyssey Dawn byly spokojené s počátečními zmatky ve struktuře velení a řízení (C2), kdy např. Norsko, se šesti F-16 umístěnými na Krétě, rozhodlo, že se zapojí, až bude vyjasněná situace se systémem velení a řízení. Teprve poté, co NATO převzalo velení operace v Libyi, se stal systém velení a řízení konsolidovaný a operace začaly probíhat se společnou doktrínou, taktikou, technikou a postupy. Nicméně je třeba zdůraznit, že také NATO mělo v počáteční fázi OUP problémy s C2. Zpočátku, poté co NATO převzalo velení OUP, bylo zcela jasné, že vzdálenost mezi velitelem CFAC a jeho Operačním centrem letectva (Air Operations Center - AOC) nebyla ve struktuře nejlepší volbou k zajištění účinné a pružné reakce na dynamickou povahu operace. Bylo potřeba CFAC umístit společně s AOC. A za druhé, ze zkušeností víme, jak je někdy těžké skloubit národní zájmy se zájmy NATO. Během neformálního setkání se stálými zástupci členských států NATO generál Charles Bouchard zdůraznil, že v průběhu fáze operačního plánování OUP nebyly vždy kvůli národním kulturním rozdílům národní cíle v souladu s cíly NATO. [3]

\section{Znalost situace a protivníka jako základní prvek plánování operace}

Fáze rozpracování targetingu popisuje proces analýzy a rozbor problému, který má za úkol poznat záměry soupeře nebo válčících stran a najít způsoby, jak je přímo či neprrímo přesvědčit či ovlivnit tak, aby bylo přijato to, co je považováno mezinárodním společenstvím za přijatelné. Cílem tohoto procesu je vytvořit seznam cílů, u kterých by mělo být poté, co na ně bude působeno kinetickou nebo nekineticku silou, dosaženo požadovaných efektů. Aby bylo možné vybrat ty správné cíle a vytvořit správné účinky a dosažení cílů, je nutná komplexní znalost situace nebo protivníka. To je důvod, proč je tato fáze targetingu tak závislá na tzv. procesu zpravodajských informací, využívání a šíření (Production, Exploitation, Dissemination - PED). Je třeba identifikovat krizi nebo soupeřovo zázemí, jeho kritické schopnosti a pravděpodobné úmysly. Úmyslem je analyzovat problém, dostat se do kritických oblastí nebo do systému, a to do natolik důležitých, aby se mohly stát cílem. Tento proces závisí na technologiích a lidské schopnosti zjistit informace o nepř́iteli.

Např́klad v Libyi byl IADS složen z protiletadlového dělostřelectva, zařízení včasného varování a plochy pro letecké rakety nebo skladování střeliva. Cíle pozemních síl byly rozdělené na pozemní logistické jednotky, obrněné transportéry, obrněná vozidla, jednotky připravené k nasazení nebo dokonce civilisté připravení k nasazení. [4] Jednoduše řečeno, bez zpravodajských jednotek není možný proces targetingu. Když začalo NATO aplikovat rezoluci Rady bezpečnosti OSN 1973, byl tento proces dalek plné vyzrálosti, a to z několika důvodů. Za prvé, na začátku (v prvních dnech operace Odyssey Dawn), nebyl pro efektivní operační plánování dostatek operačních údajů a informací o libyjském režimu. Libye nebyla považována po dlouhou dobu za hrozbu, takže nemohlo být zahájeno pokročilé plánování a Kaddáfího reálné schopnosti byly neznámé. Když vyvstala potřeba zahájit akci, zpravodajská služba nebyla připravena podpořit tak vysoké tempo této kinetické operace. Za druhé, když US zahájily koaliční údery na Libyi, nebylo dost průzkumných prostředků ISR jako je E-3 AWACS, E-8 JSTARS nebo bezpilotních vzdušných prostředků, jako je RQ-4 Global Hawk, aby dodávaly 
informace pro operační plánování, pro zpravodajské složky a proces targetingu. Důvod byl ten, že byly tyto prostředky použity někde jinde, konkrétně v Afghánistánu. Za třetí, v době, kdy byla zahájena OUP, byl problém s ISR prostředky sice již vyřešen, ovšem za účelem zahájení procesu PED, je důležité mít celou skupinu specializovaných a dobře vyškolených odborníků, jako jsou zpravodajští analytici a tzv. „targetýřri“ (targeteers). NATO prostě nemělo dostatek těchto pracovníků pro zahájení procesu PED, aniž by nebylo závislé na dobré vủli národních sil.

Když se velitel společných vzdušných sil Combined Forces Air Component Commander pro OUP generálporučík Ralph Jodic rozhodl spojit CFAC a AOC, rychle si uvědomil, že proto, aby bylo možné dosáhnout efektivního velení a kontroly nad leteckými operacemi v Libyi, je za potřebí pro CFAC a AOC více kvalifikovaných specialistů pro targeting, a to jak pro záměrný targeting, tak pro dynamický targeting. Pro dokreslení je nutné uvést, že př́slušníci skupiny pro targeting vykonávali tuto funkci pouze několik týdnů před tím, než byli vystřídáni v pravidelném cyklu do svých pozic, což jim neumožnilo plně se kvalifikovat a získat v této oblasti důležité zkušenosti.

NATO na tento stav reagovalo zvýšenou snahou vytvořit za podpory národních prvků Společné zpravodajské centrum př́ipravy pro operační prostředí (Joint Intelligence Preparation of the Operation Enviroment - JIPOE). Tato integrace národních prvků, styčných důstojníků (Liaison Officers - LNOs) a zpravodajských důstojníků (Intelligence Officers - NIC) do struktury C2 na taktické úrovni napravila počáteční nedostatky. V CFAC bylo více než 200 styčných důstojníků z téměř 400 zaměstnanců. V CJTF UP HQ byla vytvořena fúze zpravodajských buněk se schopností produkovat pro NATO vlastní informace, které mohly být předávány jednotlivým členským státům a partnerům. Tento krok, fůze zpravodajských buněk, byl jedním z rozhodujících momentů, který přispěl k úspěchu celé operace.

Úspěch ve válce závisí na tom, jak dobře je znám nepřítel. V asymetrickém ozbrojeném konfliktu má významnou roli Human Intelligence (HUMINT). Vzhledem k tomu, že v Libyi nemělo NATO oficiálně žádné pozemní jednotky, byla velice výrazně snížena schopnost splynout, pochopit a ovlivňovat operační prostředí. Ačkoli v Libyi nebyly nasazeny oficiálně žádné pozemní jednotky, pohybovalo se na tomto území mnoho tzv. „,vojenských poradců“ spojených s libyjským Národním nestálým výborem (National Transitional Council - NTC) a jeho ozbrojeným křídlem rebelů. Tyto osoby poskytovaly odborné znalosti a technickou podporu a zároveň poskytovaly národním zpravodajským složkám přímý přístup $\mathrm{k}$ informacím a tímto i neprímý přístup $\mathrm{k}$ těmto informacím pro NATO. USA poslaly polovojenské agenty CIA, zatímco Francie a Británie vyslala zvláštní jednotky a někteří partneři NATO, jako byl např. Katar, který dokonce poslal několik set vojáků, kteří se spojili s vycvičenými a informovanými rebely v předních liniích. Státy jako Itálie, Bulharsko, Egypt, Jordánsko a Arabské Emiráty přispěly účastí svých speciálních sil. Toto přímé spojení s NICs a nepř́mé spojení s „pozemními silami“ v Libyi bylo zcela zásadní, nebot’ umožnilo velitelství NATO nejen porozumět a ovlivňovat operační prostředí, zlepšit proces PED a nakonec tak získat materiály pro targeting, ale také podpořilo díky zpravodajským službám celý proces targetingu. Podle některých názorů je skutečnost, že samotné NATO nemělo dostatek organických zpravodajců, tedy nemělo dostatek zdrojů, nebyla chyba, ale naopak byl nakonec tento stav $\mathrm{v}$ něčem prospěšný. Výhoda spočívala $\mathrm{v}$ prrístupu ne k jednomu, ale k mnoha zpravodajským zdrojům (např. americké, francouzské, 
britské, arabské apod.). Tímto byla i snížena pravděpodobnost zpracování nepotvrzených nebo nepravdivých výstupů.

Dalším problémem, se kterým se muselo NATO vypořádat, bylo sdílení informací. Sdílení informací byl mezi členy NATO vždy problém. Pro generála Charlese Boucharda byla fúze zpravodajských buněk zároveň jedním ze zásadních problémů z pohledu sdílení informací mezi jednotlivými národy. Během různých misí NATO mělo např. informace pouze pro americkou stranu, pouze pro tři členy nebo pouze pro pět členů a nikoli pro všechny členské státy NATO zapojené do operace. Tento problém odhaluje nedostatek důvěry mezi státy NATO a degraduje tak účinnost jednotlivých operací. I přes tento nedostatek dokázalo NATO při OUP nakonec vytěžit všechny jemu dostupné informace od jednotlivých národů. Zda byl ovšem tento proces zcela ideální, lze těžko posoudit.

\section{Použití prostředků s ohledem na kolaterální škody}

Jakmile je něco (nebo někdo) klasifikován jako cíl, je nutné určit příslušný nástroj nebo zbraň, [5] at' již se smrtícím nebo s nesmrtícím účinkem. Osoby odpovědné za tuto analýzu musí mít ty nejlepší schopnosti k tomu, aby vyhodnotily u každého cíle zásady targetingu, potažmo zásady mezinárodního práva, jako je např. zásada proporcionality nebo vojenské nezbytnosti, dále musí vyhodnocovat působení na jednotlivé cíle z pohledu ROE pro danou operaci, práva ozbrojeného konfliktu (Law of Armed Conflict - LOAC) a v neposlední řadě musí dbát na potřebu vyhnout se jakýmkoliv kolaterálním škodám, nebo je alespoň minimalizovat. Toto vše vyžaduje výborné zpravodajské zázemí, zkušené a dobře vyškolené analytiky a tzv. weaponeers (zbraňoví analytici) a nastavené jasné postupy. Během OUP byly velké obavy o civilní oběti. Oficiální zprávy NATO uvádí, že byly letecké útoky provedeny s nebývalou precizností tak, aby se zabránilo civilním obětem (Civilian Casualities - CIVCAS). V podstatě při každém odhadu analýze možných kolaterálních škod (Collateral Demage Estimate - CDE) a během mise, pokud vyvstane jakákoli pravděpodobnost způsobení útokem civilních obětí, je tento útok neprrípustný.

V průběhu OUP muselo několik zemí upustit od použití tzv. přesně naváděných střel - Precision Guided Munition (PGMs). V polovině června 2011 použilo dánské letectvo více než 500 PGMs a jeho zásoby se tím hodně snížily. Velká Británie měla ten samý problém. Účastnící se státy nečekaly, že operace bude trvat déle než tři měsíce. Státy jako Kanada, Norsko, Belgie a Dánsko si uvědomily, že mají problémy udržet krok s operačním tempem. Na tento problém reagovaly USA tím, že umožnily dodání zbraní v rámci programu tzv. Foreign Military Sales Program (FMS). Polsko, které se př́imo neúčastnilo OUP, taktéž začalo prodávat tuto potřebnou munici dalším státům NATO. [6] Zbrojařské firmy si uvědomily, že je potřeba zlepšit funkčnost PGMs a státy si zase vykalkulovaly, že je potřeba mít větší zásoby. Názory se na to, zda nedostatek PGMs způsobil menší dynamiku leteckých úderů, se liší, ale co lze s jistotou říci, je, že se uskutečnila pouze třetina plánovaných leteckých úderů na den. Ovšem dle oficiálních prohlášení toto nebylo způsobeno nedostatkem munice. Skutečnost, že NATO během nedostatku PGMs nepoužila jiný typ munice, dokazuje odhodlání členských států výrazně minimalizovat kolaterální škody. 


\section{Synchronizace a potřeba nasazení specialistư při OUP}

Pro potřeby operace je nutné synchronizovat, koordinovat a stanovit priority dostupných sil, smrtících nebo nesmrtících prostředků, a to za účelem dosažení prioritních cílů. Účelem tzv. synchronizace jednotlivých prvků (Campaign Synchronisation) je vytvořit synergický efekt mezi společnými silami při dodržování ROE, LOAC a vyšší úrovně velení a řízení. Typicky JOPG ze Společného operačního oddělení (v rámci operačního velitelství na CJTF HQ) provádí dlouhodobé plánování (10 dní a více), zatímco Společná koordinační rada (Joint Coordination Board - JCB), vytvořená u Společného koordinačního centra, je odpovědná za synchronizaci tohoto dlouhodobého plánování pro aktuální operaci (až pro tři dny) vytvořená u Společného operačního centra. Rozkaz společné koordinace (Joint Coordination Order - JCO) je dokument JFC sloužící k posílení jeho velení a řízení. JCO poskytuje společný návod pro targeting, vyrovnává konkurenční požadavky jednotlivých komponentů a synchronizuje nasazení sil a prostředků. Stručně řečeno, jak doktrína NATO říká, JCO stanoví směr pro integraci dostupných sil a prostředků v souladu s operačním záměrem.

V úvodních etapách operace Odyssey Dawn byla prioritou ochrana 750000 obyvatel v Benghází před velkou koncentrací obrněných vozidel blížících se k městu, tak aby nedošlo k masakru, a pak vyřadit Kaddáfího IADS. Poté, co začalo být Benghází a vzdušný prostor bezpečný, posunula se priorita k cílům, jakým bylo např. Libyjské velení a řízení.

K realizaci pokynů JCO a k dodržování OPLAN, a to za účelem vyvíjení účinného tlaku na protivníka a k dosáhnutí požadovaných účinků, je nutné mít k dispozici dostatečný počet sil s potřebnými specifickými schopnostmi, vybavenými, vycvičenými a bez národních výhrad tzv. CAVEATS.

OUP se zúčastnilo 18 zemí, 14 členů NATO (z 28) a 4 partneři. Celkem se zúčastnilo OUP 250 letadel, bylo použito 6500 PGMs a bylo zasaženo 5900 cílů. Tato čísla zakrývají tu skutečnost, že NATO bylo př́liš závislé na kritických schopnostech poskytovaných USA, jako je SEAD / EW, AAR a zejména ISR. Persistentní ISR byla poskytnuta ozbrojenými bezpilotními prostredky - drony (Unmanned Aerial Vehicle - UAV), které byly pro NATO dostupné pouze 20. dubna 2011. Tyto prostředky byly totiž hojně využity v té době v jiných operacích. Perzistentních ISR prostředků jako např́iklad RQ-4 Global Hawk, který je schopen sbírat zpravodajský obraz (Imagery Intelligence - IMINT) o 300-400 cílech za jednu misi, jsou velmi důležité pro utvoření si celkového obrazu pro fázi před útokem. Úspěch kinetického targetingu se zaměřením na prevenci kolaterálních škod je silně závislý na schopnosti vizualizace cílové oblasti a tedy i vizualizace možných kolaterálních škod. Nehledě na to, že vizualizace fáze po útoku přsispívá k procesu vyhodnocení škod boje tzv. Battle Damage Assessment (BDA), a lze tedy dovodit, že je důležité mít ISR prostředky k dispozici. Vzhledem $\mathrm{k}$ nedostatku ISR prostředků a $\mathrm{k}$ nedostatečnému počtu vyškolených zpravodajských analytiků, targetýrů a tzv. weaponeers, bylo NATO silně závislé na dodávkách materiálů pro targeting na dobré vůli jednotlivých národů. Během OUP bylo přibližně $85 \%$ všech schopností ISR amerických. 


\section{Použití dynamického targetingu a vyhodnocení OUP}

V tomto momentu je důležité rozlišit záměrný a dynamický targeting. Ve své podstatě je celý targeting záměrný do té doby, dokud je dostatek času na precizní plánování, dostatek výstupů zpravodajských složek pro proces targetingu, dostatek času k sestavení tzv. targeting složek, k jejich priorizaci, validaci a jejich začlenění do normálního např. ACO cyklu.

Realita je ovšem jiná. Krize nemají naplánovaný scénář a z analýz proběhlých operací lze říci, že nebyl k dispozici dostatek ISR prostředků nebo HUMINT podpory k uskutečnění záměrného targetingu. Realita je tedy taková, že dříve, než začne probíhat operace, jak se to stalo v Libyi, Společné síly upustí od záměrného targetingu a targeting se stane dynamickým. Některé cíle jsou neznámé do té doby, než se samy někde objeví. Pokud je nějaký cíl identifikován prŕliš pozdě a není čas ho zařadit do targeting cyklu, pak se stane dynamickým cílem. A praxe nám ukazuje, že v asymetrických ozbrojených konfliktech je více dynamického než záměrného targetingu. Během OUP bylo pouze 10 \% cílů záměrných, ve zbytku se jednalo o dynamický targeting.

Důkazy nám dokládají, že nebyl proveden před zahájením OUP formální nebo doktrinální targeting. Toto bylo z části způsobeno tím, že nebylo k dispozici dostatečné množství zpravodajských informací o Libyi a z toho důvodu nebylo zpracováno dostatečné množství složek targetingu na podporu této kinetické operace. Vzhledem k nedostatku prostředků ISR na začátku operace Odyssey Dawn byly podpora operací i proces targetingu prováděny prrímo posádkami letadel při leteckých misích. V tomto typu mise s názvem Strike Coordination and Reconnaissance (SCAR) se stíhači dostávají do jakési role leteckých návodčích - leteckých bojových velitelů s funkcí sekvenční a nebojovou, s uplatněním více průletů do - a ven z cílových oblastí. Taktéž podávaly posádky informace ostatním koaličním letadlům. Tyto posádky se musely pohybovat v nižších nadmořských výškách, musely vyhodnotit kolaterální škody a musely se samy rozhodnout, zda použít zbraň. Zde vyvstává jedna otázka: Bylo toto to nejlepší řešení, ponechat rozhodování na posádce letadla, aby bez dalšího rozhodla o útoku a tím nesla odpovědnost za případné vzniklé kolaterální škody? Nicméně, během prvních dvou týdnů Odyssey Dawn s USA v čele, zasáhly síly koalice každý zjištěný cíl Kaddáfího systému protivzdušné obrany a velení a řízení, což připravilo půdu následným leteckým operacím. Libye měla k dispozici přes 400 raket země-vzduch (surface-to-air missiles - SAM) a zhruba 500 kusů odpalovacích zařízení apod. Velkou část záměrných cílů bylo u libyjských pozemních sil, kdy se jednalo např. o raketomety či tanky, které Kaddáfí používal i proti civilnímu obyvatelstvu.

Důležitým momentem targetingu je pozitivní identifikace cíle tzv. PID. V procesu targetingu je to opravdu jeden ze stěžejních momentů. Dle NATO doktríny [7] platí, že je-li cíl pozitivně identifikován, musí právní poradce potvrdit, že cíl a působení na něj je v souladu s mandátem operace, OPLAN, LOAC, ROE nebo zásadami targetingu atd. Například během OUP bylo zakázáno ničení civilních komunikačních antén, nebot' mandát OSN povolil útoky jen na cíle, které ohrožují civilní obyvatelstvo nebo civilní obydlené oblasti. Je-li cíl platný a legitimní, pak dalším krokem je určení CDE. Analytik CDE zakreslí umístění cíle za účelem vyhodnocení možných kolaterálních škod a určí nejvhodnější použití síly (zbraňových systémů apod.). CDE analýza 
dbá na sladění použití zbraní a taktiky, aby bylo zabráněno ztrátám na lidských životech nebo majetku. Zde je opět nutná prrítomnost právního poradce, který vyhodnotí legálnost tohoto kroku. Různé hodnoty $\mathrm{CDE}$ určují různé úrovně oprávnění k působení na daný cíl. Nejdůležitější ze všeho je to, že po všech těchto procesech je tzv. národní červená karta jednotlivce (Red Card Holder - RCH) stále schopna zastavit útok. V rámci NATO se dbá na extrémní opatrnost při ničení cílů. Kroky NATO v této oblasti při OUP byly vyvážené a v souladu s mezinárodním právem. NATO Doktrína uvádí, že „odpovědnost za zákonný targeting je na mnoha úrovních“. Ti, kdo targeting řídí, ti, kdo ho organizují, a ti, kteří ho vykonávají. Přesto bychom neměli zapomínat, že účast NATO při OUP byla závislá na silné regionální podpoře od arabských partnerů a stavu libyjského civilního obyvatelstva trpícího pod útoky NATO by nikdy nepodpořily záměr NATO chránit civilní obyvatelstvo.

Poslední fáze procesu targetingu je vyhodnocení útoku, které dokládá, zda bylo nasazení úspěšné, zda bylo použití taktiky správné, zda se jednalo o očekávané účinky a zda jsou nutná další opatření. Hodnocení boje zahrnuje tzv. vyhodnocení bojových škod (Battle Damage Assessment - BDA), vyhodnocení účinků použití zbraně (Weapon Effectiveness Assessment) a např. doporučení k opětovnému útoku (Re-attack Recommendation). To znamená, že se vyhodnocuje, zda došlo k zasažení cíle, jaký je rozsah poškození a zda byl dosažen záměr velitele. A co je nejdůležitější, toto vyhodnocení útoku ukazuje, zda vyvolaly taktické akce správné účinky v rámci celkové strategie operace. Vyhodnocení útoku je základním prvkem v rozhodovacím cyklu a je vysoce závislé na schopnostech zpravodajských složek, at' už se jedná o zpravodajskou techniku, nebo o lidský potenciál. Poté, co se Kaddáfího jednotky odchýlily od normálních bojových taktik a zahájily asymetrickou taktiku v městské zástavbě, bylo pro NATO nutné zapojit silný zpravodajský komponent k dodání informací o pohybu Kaddáfího jednotek. Vzhledem k nedostatku potřebných ISR prostředků a vzhledem k nedostatku sdílených zpravodajských informací jednotlivými členskými státy bylo vyhodnocování v této fázi velice slabé. Jednotlivé státy na vlastní pěst posílaly do Libye své speciální síly, které umožnily přístup k požadovaným informacím. Ve vojenské operaci je fáze vyhodnocení velitelovýma očima a ušima. Bez schopnosti vyhodnocení bude voják bojovat slepý a hluchý a bude závislý na soupeřově milosrdenství.

\section{Závěr}

Podíváme-li se do Společné doktríny targetingu [8], „pozice Spojených států je ta, že pro danou operaci musí být dosažena dohoda na jednotné metodice a strategii pro kolaterální škody a CDE, včetně standardizace prostředků a metodik, s cílem zachovat jednotu úsilí a operačního úspěchu“. Operace NATO OUP v Libyi ukázala, že na půdě NATO je sice velice obezrretně používán proces targetingu a je zde snaha o synchronizaci národních prvků při vedení operací, ale že právě OUP odhalilo několik stěžejních kritických míst, které negativně ovlivnily průběh celé operace, at’ se již jednalo o nedostatek zpravodajských informací, nedostatek ISR prostředků, zprvopočátku neefektivní systém velení a řízení, či nedostatek vycvičených a vyškolených odborníků na targeting, nejednotné postupy jednotlivých národů a v neposlední řadě nejednotné 
sdílení informací mezi účastnícími se národy. Admirál James G. Stavridis uvádí: „Pouze NATO může poskytnout společnou strukturu veleni a schopnosti k potřebnému plánování a uskutečnění komplexní operace. Multilaterální koalice postavená na základě vzniklé potřeby naopak nemá žádnou společnou doktrínu pro vedení vojenských operací, nemá žádné společné schopnosti nebo velitelskou strukturu pro rychlou integraci národních síl do soudržné struktury a nemá žádné stálé mechanismy pro projednávání a pak pro rozhodování se o dohodnutém dalším postupu. "

Targeting jako stěžejní stavební kámen každé operace se díky OUP posunul dopředu, a to nejen z pohledu velení NATO, ale i z pohledu jeho členských států. OUP ukázalo, že pokud se byt' jediná část procesu targetingu vynechá nebo není dostatečně aplikována, může mít tento nedostatek nedozírné následky. OUP mělo jediný cíl, a to ochránit civilní obyvatelstvo. Jen díky dobré adaptabilitě NATO a jeho pružné reakci v aplikaci targetingu při OUP byla operace úspěšná a bylo tak zabráněno kolaterálním škodám na civilním obyvatelstvu.

\section{Poznámky k textu}

[1] NATO doctrine "Joint targeting is the process of determining the effects necessary to achieve the commander's objectives, identifying the actions necessary to create the desired effects based on means available, selecting and prioritizing targets, and the synchronization of fires with other military capabilities and then assessing their cumulative effectiveness and taking remedial action if necessary."

[2] C. Lisbon, C., 2012. Interview about Targeting during OUP [Interview] (February 2012).

[3] Informal Meeting with Gen.Charlie Bouchard. Brussels: DELNATO. 2011.

[4] C. Bouchard, NATO and Libya - The Commander's view: , We stayed the course " [Interview] (31. 10. 2011).

[5] AJP-3.9 "appropriate capabilities in order to achieve the JFC's objectives", ACO Directive 80-70 refers "appropriate tool or weapon (lethal or non-lethal) in order to chieve the desired effect". The author defends the basic idea in both documents is the same: phase 3 is about selecting the "instrument" that assures the right effects are created when engaging a certain target.

[6] J. G. Stravridis, and I. H. Daalder, "NATO's Victory in Libya: The Right Way to Run an Intervention," Foreign Affairs. 2012. Volume 91, p. 4.

[7] NATO has a defined CDE methodology align with individual nations, in order to have a standardized method among nations. The fact nations do it the same way accelerates the decision process.

[8] NATO, AJP-3.9 - Allied Joint Doctrine For Joint Targeting. 2008.

\section{Seznam použitých zdrojů}

BOOTHBY, W. H. The Law of Targeting. 1. ed. Oxford UK: OUP Oxford, 2012. ISBN-13: 978-0199696611.

BAKER, J. E. The Role of the lawyer in war, a contextual approach to targeting decisions and the commander. 2003. Chin, 4 Chi J intí L 407.

BARUCH, P. S., NAUMANN, N. Warning civilians prior to attack under international law theory and practice. 2010. 87 International Law Studies 359.

BEN-NAFTALI, O., MICHAELI, K. R. We must not make a scarecrow of the law - A legal analysis of the Israeli policy of targeted killings. 2003. 36 Cornell Int'1 L J 233.

BOIVIN, A., SANDOZ, Y. The Legal Regime Applicable to Targeting Military Objectives ind the Context of Contemporary Warfare. 2004. Law Review s. 98.

BOUCHARD, C. NATO and Libya - The Commander's view: We stred the course. Interview. 2011.

BROWN, J. M. To Bomb or Not to Bomb? Counterinsurgency, Airpower and Dynamic Targeting. 2007. Air Space Power Journal s. 75-85.

CARBERRY, J. K., HOLCOMB, M. S. Target selection at CFLCC: A lawyer's perspective. 2004. Field Artillery March - June s. 39.

CETINKAYA, O., YILDRIM, Y. Architecture Considerations of Time Sensitive Targeting and NATO TST Tool. 2013. NCI Agency. 
CORN, G. S., CORN, G. P. The Law of Operational Targeting: Viewing the LOAC Through an Operational Lens. 2012. Texas International Law Journal, Vol. 47, 337-380.

DARLING, P. Joint Targeting and Air Support in Counterinsurgency, How to Move to Mission Command. 2012. Air and Space Power Journal, s. 49-63.

DASKAL, C. J. The Geography of the Battlefield: a Framework for Detention and Targeting Outside the HOT Conflict Zone. 2013. University of Pennsylvania Law Review, Vol. 161, No. 5, s. 1165-1234.

FORD, M. Precision targeting and the industrialisation of the Intelligence Cycle on the battlefields of Iraq and Afghanistan. 2013. Inteligencia y Securidad 13, s. 221-243, ISSN 1887-293X.

GAUB, F. Six Strategic Lessons learned from Lybia: NATO's Operation Unified Protector. 2012. NATO Defense College.

GORDON, A. Purity of Arms, Preemptive War and Selective Targeting in the Context of Terrorism: General Conceptual and Legal Analyses. 2006. University of Haifa, 29, s. 493-508.

HAIKIMI, M. A. Functional Approach to Targeting and Detention. 2012. Michigan Law Review, Vol. 110, S. $1365-1420$.

KABA, M. Targeting the World. 2009. Global Security, s. 32-37.

KNOOPS, G. J. A. Military Criminal Responsibilities for Targeting Suspected Terrorists within (International) Armed Conflicts: Towards a Uniform Framework. 2008. International Criminal Law Review, 8, s. 141-160.

MALER, CH. S. Targeting the city: Debates and silence about the aerial boxing of World War II. 2005. International Review of the Red Cross, Vol. 87, No. 859, s. 429-444.

PRICE, B. C. Targeting Top Terrorists, How Leadership Decapitation Contributes to Counterterrorism. 2012. International Security - Harvard College, Vol. 36, No. 4, s. 9-46.

ROMAO, R. Targeting and Adaptation in Combat. 2013. Baltic Security and Defence Review.

STAVRIDIS, J.G., DAALDER, I.H. NATO's Victory in Libya: The Right Way to Run an Intervention. Foreign Affairs. 2012. Volume 91. s. 4

SVENDSEN, A.D.M. NATO, Libya Operations and Intelligence Co-Operation - a Step Forward. Baltic Security and Defense Review. 2011. Volume 13 (2), s. 51-60

TYLOR, C. Military Operations in Libya. 2011. Dostupné z <http://www.parliament.uk/briefing-papers/ SN05909>.

WALlACE, D REEVES, S. R. The Law of Armed Conflict's Wicked Problem: Levee en Masse in Cyber Warfare. 2013. International Law Studies, 83 Int'1 L. STUD. Vol. 89, s. 646-668.

WALLENSTEEN, P. GRUSELL, H. Targeting the Right Targets? The UN Use of Individual Sanctions. 2012. Global Governance 18, s. 207-230.

ADDP 3.14. Targeting. 2006. Australian Defence Doctrine Publication.

AJP-3.9. Allied Joint Doctrine for Joint Targeting. 2008.

AJP-3.9.2. Land Targeting. Brusel: May 2006. NATO, $38 \mathrm{~s}$.

FM 3-60 (FM 6-20-10) Field Manual. The Targeting Process. 2010. Washington, HQ US Army.

JP 2-01.1 Joint Publication. Joint Tactics, Techniques, and Procedures for Intelligence Support to Targeting. 9 January 2003. USAF.

JP 3-05.5 Joint Publication. Joint Special Operations Targeting and Mission Planning Procedures. 10 August 1993, USN

JP 3-09 Joint Publication. Joint Fire Support. 13 November 2006. HQ US Army.

JP 3-09.1 Joint Publication. Joint Tactics, Techniques and Procedures for Laser Designation Operations. 28 May 1999. US Navy.

JP 3-60 Joint Publication. Joint Targeting. 31. January 2013. HQ US Army.

JP 3-60 Joint Doctrine for Targeting. 17 January 2002. HQ US Army.

Joint Fires and Targeting Handbook. 19 October 2007. JWC Suffolk Virginia, JCD Norfolk Virginia, US Air Force, US Army.

Multi-Service Publication FM 90-36/MCRP 3-1.6/NWP 3-60 TP/AFTTP(I) 3-2.3, The Joint Targeting Process and Procedures for Targeting Time-Critical Targets.

Multi-Service Publication FM 90-43/MCRP 3-42.1A/NWP 3-01.13/AFTTP(I) 3-2.24, Multiservice Procedures for Joint Theater Missile Target Development 